\title{
HABER ÇERÇEVELEME VE COVID-19: CRI TÜRK HABER PORTALI INCELEMESI
}

\section{Oben Hüseyin SAZANER ${ }^{1}$}

\section{öz}

\section{Araştırma Makalesi}

\section{Research Article}

${ }^{1}$ Arş. Gör.

Çankaya Üniversitesi iktisadi ve İdari Bilimler Fakültesi, Ankara, Türkiye

$$
\text { E-Posta }
$$

osazaner@cankaya.edu.tr

\section{ORCID}

0000-0002-2865-3420

\section{Başvuru Tarihi / Received} 23.04.2021

\section{Kabul Tarihi / Accepted} 03.09.2021
Medya, toplumsal dünyamızda cereyan eden hadiseleri birer haber öyküsüne dönüştürürken muhtelif haber çerçevelerinden yararlanmaktadır. Söz konusu çerçeveler, medya örgütünün politik-ideolojik temayülleri, ekonomik çevrelerle olan münasebetleri vb. saiklerin tesirinde ortaya çıkmaktadır. Dolayısıyla haber metinlerindeki çerçevelerin izini sürmek suretiyle ilgili medya örgütünün bakış açısı ve ekonomi-politik münasebetlerine ilişkin birçok veri elde edilebilir. Bu noktadan hareketle bu çalışmada CRI TÜRK Haber Portalı'nda yayınlanan Covid-19 salgınına ilişkin haberlerin ne şekilde çerçevelendiği incelenmiştir. CRI TÜRK Haber Portalı'nın Çin hükümetinin yayın organı olması hasebiyle bu çalışmanın temel amacı Çin hükümetinin salgına yönelik bakış açısını tespit etmektir. $\mathrm{Bu}$ maksatla söz konusu haber portalında 1 Nisan 2020- 30 Nisan 2020 tarihleri arasında yayınlanan 350 Covid-19 haberi nicel ve nitel yöntemlerle incelenmiştir. Verilerin çözümlenmesi sürecinde MaxQDA bilgisayar programından yararlanılmıştır. Araştırma sonucunda konuya ilişkin haberlerde en çok kullanılan çerçevelerin iş birliği, liderlik, tedbir ve kontrol, yardım ve destek, sorumluluk ve çatışma çerçeveleri olduğu tespit edilmiştir. Bulgulanan çerçevelerin anlamları çerçevelerin politik bağlamları içerisinde tartışılmıştır.

Anahtar Kelimeler: Haber Çerçeveleme, Covid-19, CRI TÜRK. 
SAZANER, Oben Hüseyin (2021). Haber Çerçeveleme ve Covıd-19: CRI Türk Haber Portalı İncelemesi, Gümüşhane Üniversitesi İletişim Fakültesi Elektronik Dergisi (e-gifder), 9 (2), 943-975.

\title{
NEWS FRAMING AND COVID-19: A REVIEW OF CRI TURK NEWS PORTAL
}

\begin{abstract}
The media makes use of various news frames while turning the events that take place in our social world into news stories. The aforementioned frameworks appear under the influence of motives such as the politicalideological tendencies of the media organization, its relationships with economic environments, etc. Therefore, by tracing the frames in the news texts, a lot of data can be obtained regarding the perspective of the relevant media organization and its relations to political economy. From this point of view, in this study how the news about the Covid-19 outbreak published on the CRI TURK News Portal was framed is examined. Since the CRI TURK News Portal is the media outlet of the Chinese government, the main purpose of this study is to determine the perspective of the Chinese government towards the epidemic. To this end, 350 Covid-19 news published between April 1, 2020 and April 30, 2020 on the news portal mentioned above were analyzed by using quantitative and qualitative methods. In the process of data analysis, the MaxQDA computer program was used. As a result of the research, it was determined that the most commonly used frameworks in the news on this issue are cooperation, leadership, measures and control, aid and support, responsibility, and conflict frameworks. The meanings of the frames found have been discussed within the political contexts of the frames.
\end{abstract}

Keywords: News framing, Covid-19, CRI TURK.

Giriş

İlk olarak 2019 yılı Aralık ayında Çin'in Wuhan kentinde ortaya çıkan Covid19 virüsü kısa sürede bir salgın halini edinmiş ve tüm dünyayı etkisi altına almıştır. Salgın tüm ülkelerdeki toplumsal hayatı durdurmuş, uluslararası tüm münasebetler fiziki anlamda askıya alınmıştır. Bu süreçte ülkeler sağlık sistemlerini devam ettirebilmek adına sert tedbirlere yönelerek peş peşe sokağa çıkma yasakları ilan etmişlerdir. Bir yandan zikredilen gelişmeler yaşanırken, öte yandan uluslararası politikada ve iletişim mecralarında Çin'in salgındaki rolü ve iletişimsel eylemleri çokça tartışılır hale gelmiştir.

Amerika Birleşik Devletleri (ABD) Başkanı Donald Trump Çin hükümetini salgının başlangıcında dünyadan bilgi saklamakla itham etmiş ve söz konusu salgının müsebbibi olarak Çin Halk Cumhuriyeti'ni işaret etmiştir (https://www.ntv.com.tr). Avrupa Komisyonu lideri Ursula von der Leyen Çin ve Rusya’yı Covid-19 gündemini kullanarak sosyal medyada Avrupa Birliği’ni hedef alan yalan haberler ve dezenformasyon yapmakla suçlamıştır (https://www.politico.eu). Avrupa Birliği Dış İlişkiler Servisi Covid-19 salgını sürecinde yapılan dezenformasyona yönelik bir rapor yayınlamıştır. $\mathrm{Bu}$ raporda, Çin hükümet görevlilerinin ve parti medyasının 
SAZANER, Oben Hüseyin (2021). Haber Çerçeveleme ve Covıd-19: CRI Türk Haber Portalı İncelemesi, Gümüşhane Üniversitesi İletişim Fakültesi Elektronik Dergisi (e-gifder), 9 (2), 943-975.

Covid-19 salgınının kökeni hakkında kanıtlanmamış teoriler geliştirdiklerinin ve bazı Avrupalı liderlerin Çin yardımları hususundaki müteşekkirliğine ilişkin haberler yaptıklarının altı çizilmektedir (https://euvsdisinfo.eu).

Covid-19 salgını müddetince global aktörlerin söylemleri muhtelif gazetelerde yine muhtelif çerçevelerle haberleştirilmektedir. Söz konusu gazetelerin sahiplik ilişkileri, yayın yaptıkları politik-ekonomik yapı, ideoloji vb. saikler metinlerde anlamı üreten güç ilişkilerini de beslemekte; söylem, iç grup addettiği odağın menfaatlerine uygun bir biçimde kurulmaktadır. Salgın sürecinde yaşanan gelişmeler CRI TÜRK (Çin Uluslararası Radyosu) Haber Portalı'nda tabiatıyla güçlü akisler bulmuştur. Türk izleyicilere Türkiye, Dünya ve Çin hakkında doğru bilgiyi iletmek maksadıyla yayın yaptığını ifade eden CRI TÜRK (https://www.milliyet.com.tr) Çin devletinin resmi görüşünü yansıtması hasebiyle bu çalışmada konu edinilmiştir. Covid-19 salgını süresince cereyan eden hadiselerin Çin devletinin sözcüsü konumunda olan bir yayın organında nasıl çerçevelendiğinin tespit edilmesi çalışmanın temel amacıdır.

\section{Kuramsal Çerçeve}

Haber metinleri gündelik hayatta meydana gelen hadiseleri birer haber öyküsüne dönüştürürken belirli amillerin tesiriyle bir uzlaşı sonucu oluşan çerçevelerden istifade ederler. İnsanlar kendi gündelik hayatlarını dolayımsız olarak deneyimlediklerinde, mevzubahis deneyimi nasıl doğal olarak telakki ediyorlarsa çerçeveler bağlamında oluşturulan haber bilgisini de aynı doğallıkla kabul etmektedirler. Söz konusu çerçeveler kaynak, metin ve alıcı arasında zuhur eden anlama müdahale ederek anlamı sınırlandırır. $\mathrm{Bu}$ sınırlandırılmış anlamlar manzumesi ise müstakil bir toplumsal gerçek inşa eder. Yani, haber metinleri toplumsal gerçekliği inşa eden bir enformasyon biçimidir (Dursun, 2004: 43). Stuart Hall, medyada yer alan şeylerin olduğu gibi aktarılmadığını, burada bir aktarma ya da yansıtmadan ziyade anlamlandırma faaliyetinin olduğunun altını çizerken, “...gerçeklik basitçe verili bir olgular dizisi değildir; gerçek, gerçekliğin belirli bir tarzda kurulmasıdır. Medya gerçekliği yalnızca üretmez; ayrıca onu tanımlar” diye ifade etmektedir (1994: 67-68). 
SAZANER, Oben Hüseyin (2021). Haber Çerçeveleme ve Covıd-19: CRI Türk Haber Portalı İncelemesi, Gümüşhane Üniversitesi İletişim Fakültesi Elektronik Dergisi (e-gifder), 9 (2), 943-975.

Değinildiği gibi basın ekonomi-politik, profesyonel ideoloji vb. etkenlerle çerçevelerini kurmaktadır. İlgili çerçeveleri kurduktan sonra aynı çerçeveleri benzer hadiselere de uyarlamakta ve çerçeveleri sürekli kılmaktadır (İnal, 1995:112). Çerçevelerin bileşenleri genellikle kurulu söylem alanlarıyla insicamlı bir ilişki içerisindedir. Bu çerçevelerde maksadın hâsıl olmasını sağlayacak sözcükler ve görseller mükerrer biçimde öne çıkarılır ve okuyucunun bilişsel süreçlerinin etkilenmesine çalışılır (Entman, 1991: 11). Dolayısıyla, medyanın kamuoyunu biçimlendirmesinin en etkili yollarından biri aktarılan konunun çerçevelenmesidir (Vreese, 2005: 51). Çerçeveleme esas olarak seçim ve dikkat çekmeyi içerir. Çerçevelemek, algılanan bir gerçekliğin bazı veçhelerini seçmek ve bunları, tanımlanan öğe için belirli bir problem tanımı, nedensel yorumlama, ahlaki değerlendirme ve/veya bir davranış önerisini teşvik edecek şekilde iletişim metninde daha belirgin hale getirmektir (Entman, 1993: 52).

Medya çerçeveleri, toplumsal dünyayı hem haber üretimi gerçekleştiren gazeteciler için hem de söz konusu haberleri okuyan ve değerlendiren okuyucular için düzenler. Bu doğrultuda denilebilir ki çerçeveler, söylemi organize eden sembol işleyicileri vasıtasıyla vücuda getirilen kavrama, yorumlama, sunum, seçme, vurgulama ve dışlama kalıplarıdır. Gazeteciler çerçeveler yoluyla büyük bir miktarda enformasyonu hızlı ve istikrarlı bir şekilde düzenler, onları bilişsel kategorilere uygun olarak tasnif eder ve sürecin sonunda okuyucular için uygun hale getirir. Bir başka deyişle, çerçeveler örgütsel süreçler mucibince kaçınılmaz modellerdir. Buradan hareketle, metinler tetkik edilirken "buradaki çerçeve nedir?" "Neden bu çerçeve de başka bir çerçeve değil?” gibi soruların sorulması elzemdir (Gitlin, 1980:7).

Çerçeveler bazı düşünceleri haber metninde daha görünür hale getirip bazılarını geri plana iterken; bunu anahtar kelimeler, metaforlar, kavramlar ve semboller aracılığıyla gerçekleştirir. Çerçeveler temel argümanın aksi argümanlara da yer verebilir. Ancak burada çerçeveyi oluşturan sözcükler ve görseller temel argümanı diğerlerinden daha dikkat çekici ve daha kolay anlaşılır kılar (Entman, 1991: 7). Ancak çerçeveleme yalnızca metin ya da medya içeriği kapsamında değerlendirilebilecek bir pratik değildir. Bir çerçevenin varlığı iletişimciler, 
SAZANER, Oben Hüseyin (2021). Haber Çerçeveleme ve Covıd-19: CRI Türk Haber Portalı İncelemesi, Gümüşhane Üniversitesi İletişim Fakültesi Elektronik Dergisi (e-gifder), 9 (2), 943-975.

izleyiciler-okuyucular, medya içeriği ve toplumsal bağlam arasında cereyan eden temel bir ilişkinin varlı̆ğ anlamına gelmektedir. Bu doğrultuda çerçeveleme işlemi bir süreç olarak görülmelidir (Yang, 2012: 64).

Bir haber metnindeki çerçevelerin ortaya çıkarılması metnin bağlamının tüm boyutlarıyla ele alınmasıyla mümkündür. Çerçeve olarak değerlendirilen kritik sözcük ya da görseller toplumsal bağlam içerisinde mana kazanırlar. Ancak böyle bir nokta-i nazardan bakıldığında metnin vurguladığı anlam idrak edilebilir (Entman, 1991: 8). Yine bu zaviyeden bakarak -bilhassa Covid-19 gibi ihtilaflı kriz dönemlerinde- haber metninin hangi gücün söylemini hakikat kıldığg1, kimin durum tanımlarını yadsıdığı ya da yanlışladığı müşahede edilebilir. Zira Entman'ın (1993: 55) belirttiği gibi, haber metni gücün tecessüm ettiği alandır ve metne egemen olmak için mücadele eden aktörler ve çıkarlar bu alanda görüngüleşir.

Hertog ve McLeod'a göre (2001: 144-145), çerçeveler toplumsal dünyayı ve fenomenleri kabaca beş biçimde yapılandırır: İlk olarak çerçeveler, içeriklerin toplumsal veçhesini tayin eder. Diğer bir deyişle, bireysel fenomenlerin, kavramların ve fikirlerin bir konu altında kategorize edilmesi bir çerçeveleme pratiğidir. Mevzubahis kategorizasyon süreci bir dizi kültürel seçime tekabül eder. Örneğin muhtelif fenomenleri “ekonomi” başlığı altında gruplamak kısmen keyfi bir işlemdir. İkinci olarak çerçeveler, çeşitli bireylerin, grupların, organizasyonların ve kurumların -toplumsal fenomenlerin anlaşılmasına ilişkin- oynadıkları rolleri tanımlar. Muayyen bir grup bir çerçevede sorun çözen rolündeyken, aynı grup bir başka çerçevede tali bir rol oynayabilir ya da sorunun bizatihi kaynağı olarak işaretlenebilir. Üçüncüsü, çerçeveler inançların, değerlerin ve eylemlerin makbul olup olmadığına ilişkin bilgi ihtiva eden modellerdir. Kimi ilişkiler olumlanırken, kimi ilişkiler uygunsuz ve gayrimeşru olarak addedilir. Dördüncüsü, metindeki dil kullanımı, cümle yapısı, kod niteliğindeki sözcükler çerçeve tercihinden etkilenir. Örneğin kürtaj konusunda yaşam yanlısı (prolife) bir çerçevede bebek, cinayet vb. sözcükler tercih edilirken, tercih yanlısı (prochoice) bir çerçevede kadın, özgürlük vb. sözcükler tercih edilmektedir. Son olarak çerçeveler, bir içeriğin yapılandırılması sürecine içkin olan hedef ve değerlerin altını çizmektedir. Her çerçeve, belli bir dizi hedef ve etiği diğerlerine nazaran daha ayrıcalıklı bir pozisyonda konumlandırır. Yani, bazı 
SAZANER, Oben Hüseyin (2021). Haber Çerçeveleme ve Covıd-19: CRI Türk Haber Portalı İncelemesi, Gümüşhane Üniversitesi İletişim Fakültesi Elektronik Dergisi (e-gifder), 9 (2), 943-975.

kavramlar mihver bir nokta işgal ederken, bazı kavramlar tali görevler üstlenmektedirler.

Çerçeveleme pratiği çok yönlü ve çok aktörlü dinamik bir iletişim sürecini ihtiva etmektedir. Mevzubahis süreci, çerçevelerin nasıl oluştuğu üzerine yoğunlaşan çerçeve inşası (Frame building) ve medya çerçeveleriyle okuyucular arasındaki etkileşimi imleyen çerçeve belirleme (Frame setting) gibi iki temel pratik karakterize eder. Çerçeve inşası haber metninin oluşturulma süreçlerine gönderme yapar. Çerçeve inşasının dinamikleri ancak metindeki çerçevelerin tahlil edilmesi suretiyle anlaşılabilir. Çerçeve belirleme ise medya içerikleriyle-çerçeveleriyle bireylerin bilme süreçleri arasındaki etkileşimi ifade eder. Burada kastedilen haber metinlerindeki çerçevelerin bireylerin hadiseleri ya da konuları öğrenme, yorumlama ve değerlendirme istidatlarına etki edebilme potansiyelleridir (Vreese, 2005: 51-52).

Çin gazetelerinde kullanılan haber çerçevelerini konu edinen birçok çalışma gerçekleştirilmiştir. 2003 yılında ortaya çıkan SARS salgını sırasında Amerika ve Çin gazetelerinde salgının nasıl çerçevelendiğini tetkik eden Beaudoin (2007), örneklem olarak ele aldığı Xinhua gazetesinde en çok insan ilgisi çerçevesinin kullanıldığını, yine azımsanmayacak derece ekonomik sonuçlar çerçevesinden yararlanıldığını, sorumluluk çerçevesinin ise oldukça az tercih edildiğini bulgulamıştır. Hong (2007), SARS haberlerini, biri web portalı, biri ulusal, diğeri yerel gazete olmak üzere toplam üç Çin haber merkezini esas alarak incelemiştir. Çalışmayla paralellik arz etmesi amacıyla ulusal gazete ve web portalının sonuçlarına bakıldığında, People’s Daily gazetesinde sağlık, insan ilgisi ve ekonomik sonuçlar çerçevelerinin tercih edildiğini, sorumluluk çerçevesinin yadsındığ görülmektedir. Web portalı olan Sohu'da ise yine sırasıyla sağlık, insan ilgisi ve ekonomik sonuçlar çerçeveleri kullanılırken, sorumluluk çerçevesinin oldukça az kullanıldığı görülmüştür.

Sars salgınını konu edinen bir başka çalışmada Luther ve Zhou (2005), salgının $A B D$ ve Çin gazetelerinde nasıl çerçevelendiğini ele almaktadır. Luther ve Zhou, incelediği People's Daily ve China's Daily gazetelerinin batılı gazetecilik ilkelerini benimsediklerini, farklı derecelerde de olsa Batılı gazetelerle benzer çerçeveleri kullandıklarını belirtmişlerdir. Söz konusu çalışmalardaki bulgulara göre 
SAZANER, Oben Hüseyin (2021). Haber Çerçeveleme ve Covıd-19: CRI Türk Haber Portalı İncelemesi, Gümüşhane Üniversitesi İletişim Fakültesi Elektronik Dergisi (e-gifder), 9 (2), 943-975.

Çin gazetelerinde en çok kullanılan çerçeveler sırasıyla insan ilgisi, liderlik ve ekonomik sonuçlar çerçeveleridir. ABD gazeteleri insan ilgisi çerçevesini olumsuz anlamda kullanırken (hayatta kalmaya çalışan insanlar vb.), Çin gazeteleri bu çerçeveyi daha pozitif bir yaklaşımla ele almaktadır (Hastalığı yenen bireylerin kahramanlık hikâyeleri gibi). Yang (2012), makalesinde 2003 yılındaki Sars salgını ile 2008 yılındaki Sichuan depremini konu edinerek kriz zamanlarında Çin gazetelerinde yer alan çerçeveleme pratiklerini araştırmıştır. Yang, Çin gazetelerini pazar yönelimli ve devlet gazeteleri olarak ikiye ayırmıştır. Çalışmada devlet gazetesi olarak incelenen People's Daily gazetesinde SARS haberleri, daha çok kurtarma (rescue) çerçevesi daha sonra insan ilgisi, liderlik ve sorumluluk çerçeveleri vasıtasıyla sunulmuştur. Pazar yönelimli Nanfang Weekend gazetesinde ise sırasıyla sorumluluk, insan ilgisi, kurtarma ve ekonomik sonuçlar çerçeveleri kullanılmıştır.

Koronavirüs süreci içerisinde Çin'in üstlendiği rol ve bu rolü icra ederken kullandığ1 retoriğe odaklanan Zhao (2020), Çin'in Covid-19 sürecinden -bir "koronavirüs diplomasisi” yürüterek- istifade ettiğini, salgından etkilenen ülkelere tıbbi malzeme ve uzman yardımları göndermek suretiyle uluslararası ilişkilerdeki özgül ağırlığını genişlettiğini ve ABD’nin küresel liderliğine bayrak açtığını belirtmiştir. Zheng (2020) ise, bir Çin devlet medyası olan China Daily gazetesindeki Covid-19 haberlerinde kullanılan haber çerçevelerini incelemiştir. Mezkur çalışmada çerçeveler metaforik ve gayri-metaforik olarak iki kısımda ele alınmış; en çok kullanılan metaforik çerçeve savaş çerçevesi (Salgın ile savaş) olarak bulgulanmıştır. En çok kullanılan gayri-metaforik çerçeveler ise inanç ve işbirliği çerçeveleridir.

Makalesinde, Çin Devleti'nin -kendi lokal nizamını sürdürme gayesiyle paralel olarak- yurtdışında oluşturduğu mesajların içeriğine odaklanan Jakop'a (2020) göre, Çin'in -salgındaki rolü etrafında şekillendirmeye çalıştı̆̆ı- anlatılarının en az altı unsuru mevcuttur (2020: 5-6); İlki, Çin'in salgının etkilerini kontrol altına alma çabalarının olduğundan daha kapsamlı ve başarılı şekilde gösterilmesi gayretinin mevcut olduğudur. İkincisi Çin, diğer ülkelerin salgın ile mücadele biçimlerine ilgi göstermekte ve onların aldığı tedbirleri değerlendirmektedir. ABD’nin salgın ile mücadeledeki yetersizliği iddiasının Çinli yetkilerce ifade edilmesi ilgili çabaya bir misal teşkil etmektedir. Üçüncü çabayı, Çin’in salgın ile 
SAZANER, Oben Hüseyin (2021). Haber Çerçeveleme ve Covıd-19: CRI Türk Haber Portalı İncelemesi, Gümüşhane Üniversitesi İletişim Fakültesi Elektronik Dergisi (e-gifder), 9 (2), 943-975.

mücadele çerçevesinde diğer ülkelere gönderdiği tıbbi malzemelerin ve sağladığ uzman desteğinin çok sık şekilde vurgulanması oluşturmaktadır. Dördüncü olarak, Çin'in siyasal sisteminin meşruluğunun ve kudretinin altını kalın bir şekilde çizme çabası dikkat çekmektedir. Jakop'a göre Çin'in ABD'ye yönelik eleştirilerinin içerisinde sistem eleştirisi de bulunmaktadır. Beşincisi, Çin’in sık sık kullandığ "virüsün sınır tanımadığı", "ortak düşman", "uluslararası toplumun kolektif cevabı" gibi ifadeler dikkat çekmekte ve meselenin Çin ile olan rabıtası silikleştirilmektedir. Sonuncu unsur, Çin kaynaklarının virüsün kökeni hakkında başta ABD'nin mesul olduğunu ima eden söylemleri kullanmasıdır.

\section{Araştırma Tasarımı}

Bu çalışmada Covid-19 salgını süresince Çin hükümetinin salgına yönelik bakış açısı ve kurmaya çalıştığı söylemsel gerçek CRI TÜRK Haber Portalı'ndaki haber çerçevelerinin tespit edilmesi suretiyle açığa çıkartılmaya çalışılmıştır. Söz konusu maksat doğrultusunda CRI TÜRK Haber Portalı'ndaki “Çin” başlığı altındaki Covid-19 ile ilgili haberler 1 Nisan- 30 Nisan 2020 tarihlerini kapsayacak şekilde ele alınmıştır. Mevzubahis tarihlerin seçilme nedeni salgının tüm dünyada tam anlamıyla zikredilen ay içerisinde hissedilmeye başlanması ve salgının sorumluluğuna ilişkin tartışmaların -uluslararası aktörler arasında- bu tarihler içerisinde ortaya çıkmasıdır. Örneğin 15-20 Nisan tarihleri arasında Çin'e yönelik tazminat talepleri yoğun bir şekilde tartış1lmaya başlanmıştır.

Araştırmada çift aşamalı bir analiz yöntemi takip edilmiştir. İlk aşamada CRI TÜRK Haber Portalı'ndaki Covid-19 salgını ile ilgili haberlerde kullanılan çerçeveler nicel olarak tespit edilmiştir. Haber metinlerdeki çerçeveler haber kaynakları da dikkate alınarak tespit edilirken, anlatılara hâkim olan bakış açısının gösterilmesi araştırmanın temel meselesi haline getirilmiştir. Araştırmanın ikinci aşamasında ise haber metinlerinde tespit edilen çerçevelerin nitel bir analizi gerçekleştirilmiş; kullanılan çerçevelerin yarattığı anlam tartışılmış ve yorumlanmıştır. Yine çerçevelerin olumlu ya da olumsuz bir bağlam içerisinde mi kurulduğu tartışması üzerinden mezkûr çerçevelerin mahiyeti anlaşılmaya çalışılmıştır. Haber metinlerinin ne şekilde çerçevelendiği incelenirken bilgisayar 
SAZANER, Oben Hüseyin (2021). Haber Çerçeveleme ve Covıd-19: CRI Türk Haber Portalı İncelemesi, Gümüşhane Üniversitesi İletişim Fakültesi Elektronik Dergisi (e-gifder), 9 (2), 943-975.

destekli veri analizi gerçekleştirilmiştir. Söz konusu amaçla MaxQDA 2020 programından istifade edilmiştir.

Çalışmada Covid-19 Salgını ile ilgili haberlerde kullanılan çerçeveleri tespit edebilmek amacıyla tümdengelimli ve tümevarımsal yaklaşımlar bir arada izlenmiştir. Tümdengelimli yaklaşımda literatürde daha önce kullanılmış çerçeveler tercih edilir. Böylece aynı ya da benzer konularda daha önce yapılmış çalışmalarla mukayese şansı yaratılmış olur. Tümevarımsal yaklaşımda gevşek bir çerçeve tayini söz konusudur. Bu yaklaşımda daha önce oluşturulmuş çerçevelerden yararlanılmaz; incelenen haber metninin spesifik dinamiklerine uygun yeni çerçeveler oluşturulur ve kullanılır (Beaudoin, 2007: 511).

Çalışmada hangi çerçevelerin kullanılacağı sorunu haber metinleri üç defa kodlanmak suretiyle hitama erdirilmiştir. $\mathrm{Bu}$ doğrultuda metinler tahlil edilirken toplam on iki çerçeve kullanılmıştır. Literatürde çok sık karşılaşılan ekonomik sonuçlar çerçevesi, sorumluluk çerçevesi, insan ilgisi çerçevesi (Beaudoin, 2007; Hong, 2007; Luther ve Zhou 2005; Semetko ve Valkenburg, 2000; Yang, 2012); literatürdeki bir başka sık kullanılan çerçeve olan çatışma çerçevesi (Semetko ve Valkenburg, 2000; Luther ve Zhou, 2005); ayrıca liderlik çerçevesi (Luther ve Zhou 2005), ahlak çerçevesi (Semetko ve Valkenburg, 2000) tedbir ve kontrol çerçevesi, sayılarla belirtme çerçevesi, bilimsel gelişme çerçevesi (Çeliker Saraç, 2018) bu çalışmada kullanılan literatüre ait çerçevelerdir. Tetkik edilen haber metinlerinin kendine mündemiç dinamikleri doğrultusunda üç adet çerçeve oluşturulmuş olup, bunlar: İş birliği çerçevesi, yardım ve destek ve tanık gösterme çerçeveleridir.

Ekonomik sonuçlar çerçevesi, bir olayın birey, grup, kurum ya da topyekun bir ülke üzerindeki ekonomik sonuçlarının ön plana çıkarılmasıdır (Semetko ve Valkenburg, 2000: 96). Sorumluluk çerçevesi, bir olayın müsebbibi ya da çözüm mercii olarak bir kişinin, grubun ya da siyasi erkin işaret edilmedir (Semetko ve Valkenburg, 2000: 96; Luther ve Zhou, 2005: 859). İnsan ilgisi çerçevesi, bir olay ya da problemin birey düzeyinde ve duygusal boyutlarıyla ele alınmasıdır (Semetko ve Valkenburg, 2000: 95; Luther ve Zhou, 2005: 859-860). Çatışma çerçevesi, bireyler, gruplar, kurumlar ya da devletler arası ihtilafların ve rekabetin öne çıkarılmasıdır (Semetko ve Valkenburg, 2000: 95; Luther ve Zhou, 2005: 860). Liderlik, Luther ve 
SAZANER, Oben Hüseyin (2021). Haber Çerçeveleme ve Covıd-19: CRI Türk Haber Portalı İncelemesi, Gümüşhane Üniversitesi İletişim Fakültesi Elektronik Dergisi (e-gifder), 9 (2), 943-975.

Zhou'nun ifade ettiği şekliyle, uluslararası münasebetlerin haberleştirildiği metinlerde bir ülkenin siyasi elitlerinin ismen ya da bir kabine olarak yaptı̆̆ eylemlerin ya da kurduğu söylemlerin ön plana çıkarılmasıdır (2005: 860). Ahlak çerçevesi haberde konu edinilen bir hadisenin ya da eylemin dini ya da ahlaki bir bağlamda değerlendirilmesidir (Neuman vd.'lerinden Akt., Semetko ve Valkenburg, 2000). Tedbir ve kontrol çerçevesi, gündemi meşgul eden herhangi bir olay için alınan tedbirlere vurgu yapmaktadır (Çeliker Saraç, 2018: 167). Sayılarla belirtme çerçevesi, herhangi bir olayın nicelleştirilmesi, sayılar verilerek aktarılmasıdır (Çeliker Saraç, 2018: 167). Bilimsel gelişme çerçevesi ise bir olayın menfi sonuçlarının çözümüne ya da hafifletilmesine yönelik bilimsel gelişmelerin altının çizilmesidir (Çeliker Saraç, 2018: 167). İş birliği çerçevesi bir olayın menfi etkisini hafifletmek ya da ilgili olaya önlem almak için meselenin aktörlerinin dayanışma içerisinde olması gerekliliğini vurgulayan bir haber çerçevesidir. Yardım ve destek çerçevesi herhangi bir olaydan ciddi derecede etkilenen aktörlere diğer aktör ya da aktörlerce verilen desteğe gönderme yapan bir çerçevedir. Son olarak tanık gösterme çerçevesi ise, bir olaya ilişkin destekleyici yorumları doğrulayıcı ya da olayın yönetilme biçimine ilişkin eleştirileri yanlışlayıcı kimi görüşlerin kanaat önderlerinin şahitliğine başvurularak ifade edilmesini belirtmektedir.

\subsection{CRI TÜRK Haber Portalı'ndaki Covid-19 Haberlerinin Nicel Analizi}

CRI TÜRK haber portalının taranması için www.criturk.com adresine ulaşıldığında portal arayüzünde "KORONAVİRÜS” isimli, münferit olarak oluşturulmuş bir haber kategorisi olduğu görülmüştür. Ancak bu haber kategorisinin içeriğine bakıldığında, haberlerin genel olarak Covid-19 salgınına ilişkin tüm dünyadan aktarılan vakalara ve can kayıplarına ait sayısal tespitlerle kısıtlı olduğu görülmektedir. Hem bu dar çerçeveyi aşmak hem de çalışmanın temel maksadını (Covid-19 haberlerinin Çin hükümetinin sözcüsü konumunda olan bir yayın organında nasıl çerçevelendiğini tespit etmek) gerçekleştirmek için CRI TÜRK Haber Portalı'ndaki Çin'e ilişkin haberlerin yer aldığ “ÇİN” münferit kategorisi incelemeye tabi tutulmuştur. Söz konusu kategori altında yayınlanan Covid-19 salgınına ilişkin 350 haber incelenmiştir. 
SAZANER, Oben Hüseyin (2021). Haber Çerçeveleme ve Covıd-19: CRI Türk Haber Portalı İncelemesi, Gümüşhane Üniversitesi İletişim Fakültesi Elektronik Dergisi (e-gifder), 9 (2), 943-975.

Gündelik hayatta gerçekleşen hadiseler haber metinlerinde muhtelif çerçeveler vasıtasıyla aktarılırken, basın bu çerçeveleri çoğunlukla haber kaynaklarının durum tanımlarına dayandırır (İnal, 1995, 112). Bir haberde kimin ya da hangi aktörün durum tanımının öne çıkarıldığı metnin baskın anlamını tayin etmekle kalmaz, haber metninin ihtiva ettiği güç ilişkileri hakkında ipuçları da sunar.

Tablo 1. Haber Kaynakları

\begin{tabular}{|l|l|}
\hline Haber Kaynakları & Kullanılma Sayısı \\
\hline CRI & 273 \\
\hline CRI TÜRK Dış Haberler Servisi & 1 \\
\hline Lui Dong/CRI & 1 \\
\hline Xu Yanqing/CRI & 2 \\
\hline Zhang Yifu/CRI & 1 \\
\hline CGTN & 20 \\
\hline Ssemanda Allaw/CGTN & 1 \\
\hline China Daily & 26 \\
\hline Global Times & 20 \\
\hline Xu Bin/China Daily & 1 \\
\hline Tuğçe Akkaş/CRI & 2 \\
\hline TRT Spor & 1 \\
\hline iHA & 1 \\
\hline
\end{tabular}

CRI TÜRK Haber Portalı'nın Covid-19 salgınına ilişkin yayınladığı 350 haberin 280 adedi CRI, 27 adedi China Daily, 21 adedi CGTN, 20 adedi Global Times haber merkezlerine aittir. CRI (China Radio International) Çin devletinin resmi radyosu olmakla birlikte, Çin'in global ekonomik ve politik hedefleri doğrultusunda git gide güçlü bir küresel veçhe edinmiştir (Sun, 2010:60; Sun, 2014: 1897). China Daily 1981 yılında ülkedeki ekonomik reformları ve yatırım firsatlarını yabancılara tanıtmak için kurulmuş bir yayın organıyken (Luther ve Zhou, 2005:862); CTGN (China Global Television Network) Çin devletinin kamu diplomasisi çerçevesinde istifade ettiği bir haber medyasıdır (Aydemir, 2019). Global Times ise Çin dış politikasını yansıtan, küresel elit okuyucuyu hedefleyen bir haber merkezidir (Lee, 2009: 265-266). Buradan da anlaşılacağa üzere toplam 350 haberin 348 adedi Çin devletinin haber araçlarıdır. 
Tablo 2. CRI TÜRK Haber Portalı'nda Kullanılan Çerçeveler

\begin{tabular}{|c|c|c|c|}
\hline & Frekans & Yüzde & Yüzde (geçerli) \\
\hline İşbirliği Çerçevesi & 165 & 47,14 & 47,14 \\
\hline Liderlik Çerçevesi & 142 & 40,57 & 40,57 \\
\hline Tedbir ve Kontrol Çerçevesi & 134 & 38,29 & 38,29 \\
\hline Yardım ve Destek Çerçevesi & 132 & 37,71 & 37,71 \\
\hline Sorumluluk Çerçevesi & 132 & 37,71 & 37,71 \\
\hline Çatışma Çerçevesi & 120 & 34,29 & 34,29 \\
\hline Ekonomik Sonuçlar Çerçevesi & 90 & 25,71 & 25,71 \\
\hline Sayılarla Belirtme Çerçevesi & 74 & 21,14 & 21,14 \\
\hline Bilimsel ve Tıbbi Gelişme Çerçevesi & 49 & 14,00 & 14,00 \\
\hline Tanık Gösterme & 45 & 12,86 & 12,86 \\
\hline İnsan İlgisi Çerçevesi & 17 & 4,86 & 4,86 \\
\hline Ahlak Çerçevesi & 1 & 0,29 & 0,29 \\
\hline Kodlanmış BELGELER & 350 & 100,00 & 100,00 \\
\hline Kodlanmamış BELGELER & 0 & 0,00 & - \\
\hline ANALIZ EDILEN BELGELER & 350 & 100,00 & - \\
\hline
\end{tabular}

CRI TÜRK Haber Portalı'nda Covid-19 salgını ile ilgili yapılan haberlerde en sık kullanılan çerçeveler işbirliği, liderlik, tedbir ve kontrol, yardım ve destek, sorumluluk ve çatışma çerçeveleridir. İncelenen haberlerde söz konusu sık kullanılan çerçevelerin dışında sırasıyla ekonomik sonuçlar, sayılarla belirtme, bilimsel ve tıbbi gelişme, tanık gösterme, insan ilgisi ve ahlak çerçevelerinin de kullanıldığı bulgulanmıştır.

\subsection{CRI TÜRK Haber Portalı'ndaki Covid-19 Haberlerinin Nitel Analizi ve Tartışma}

Yang çalışmasında, Çin basınını parti medyası ve pazar odaklı medya olarak iki şekilde ele almıştır. Mezkûr çalışmada Yang, parti medyasının bir propaganda aracı olduğunu söylerken, pazar odaklı medyanın parti çizgisinden farklı söylemleri de barındırdı̆̆ını ifade etmektedir (2012). Freedom House'a göre ise Çin Dünya'nın en tahdit edici medya çevrelerinden birine sahip olmanın yanında; çevrimiçi haber mecralarındaki en sofistike sansür mekanizmalarını işleten ülkelerden biridir. Çin Komünist Partisi haber medyalarının mülkiyetine sahip olması hasebiyle haber yazımı üzerinde ve gazetecilerin akreditasyonu noktasında sıkı bir kontrol yürütmektedir (https://freedomhouse.org). 
Koronavirüs salgını sürecinde basın özgürlükleri üzerine yayınladıkları raporda Reporters Without Borders, Çin'de cezaevlerinde bulunan yüzü aşkın gazeteci ve blog yazarından en az üç gazeteci ve üç siyasi yorumcunun salgın ile ilgili söylem ve haberlerden dolayı tutuklandığını; aynı zamanda hükümetin sosyal medyadaki baskısını -koronavirüs ile ilişkili birçok anahtar kelimeyi sansürlemek yoluyla- artırdığını ifade etmektedir. Aynı raporda Çin Hükümeti'nin yabancı muhabirler üzerindeki kısıtlamalarını da artırdığı ve 2020 yılı başından bu yana 16 yabancı muhabirin ülke dışına çıkarıldığı zikredilmektedir (https://rsf.org).

Totaliter bir medya sistemine sahip olan bir yapının muayyen bir hadiseye ilişsin bakış açısı, görece demokratik bir medya ortamına sahip bir yapının herhangi bir hadiseye ilişkin bakış açısına kıyasla -doğası gereği- daha kolay tespit edilebilmektedir. Yayınladığı 350 adet haberin 348 adedinin Çin devlet kaynaklarına dayandığı CRI TÜRK haber metinleri tek boyutlu bir görüntü arz etmektedir. Tek sesin hâkim olduğu haber öykülerinde öne çıkarılan konular Çin hükümetinin Covid19 salgınında yürüttüğü politikaların izdüşümleri olarak okunabilir. Buradan hareketle CRI TÜRK Haber Portalı'nda tespit edilen haber çerçeveleri -en sık kullanılandan en az kullanılana doğru- aşağıdaki gibidir;

\section{İş Birliği Çerçevesi:}

CRI TÜRK Haber Portalı'nda en sık kullanılan çerçeve iş birliği çerçevesidir. Çalışma özelinde oluşturulan bu çerçeve, Çin'in bilhassa uluslararası toplumla olan iş birliği ve dayanışma gayretini ifade etmektedir. İş birliği çerçevesinin kurulduğu haberlerde -çatışılan aktör Amerika Birleşik Devletleri dâhil- tüm devletlerin ve uluslararası örgütlerin iş birliği yapmalarının gerekliliğine vurgu yapılmaktadır. İş birliği çağrıları kimi zaman Çinli kimi zaman ise yabancı politik figürlerin ve uzmanların söylemlerine dayanılarak haberleştirilmektedir. Haber metinlerinde iş birliği çerçevesi tespit edilirken yararlanılan anahtar kelime ve ifadeler : "İş birliğii”, "insanlığın ortak kader topluluğu”, "uluslararası toplumun müşterek çabaları, “dayanışma”, “ortak düşman”, "paylaşma” gibi kelime ve ifadelerdir.

CRI TÜRK Haber Portalı'nda salgın ile ilişkili olarak yayınlanan haberlerde, Çin hükümetinin salgın ile mücadele noktasında tüm dünyayı sık sık iş birliğine 
SAZANER, Oben Hüseyin (2021). Haber Çerçeveleme ve Covıd-19: CRI Türk Haber Portalı İncelemesi, Gümüşhane Üniversitesi İletişim Fakültesi Elektronik Dergisi (e-gifder), 9 (2), 943-975.

çağırdığı dikkat çekmektedir. Çin bilhassa ABD’nin kendisine yönelik ağır eleştirilerine iş birliği çağrıları ile mukabele etmekte, küresel sorumluluklar üstlendiğini ima ederek yöneltilen eleştirilerin yadsınmasını sağlamaya çalışmaktadır. Ancak iş birliği konseptinin Çin için salgına münhasır bir enstrüman olduğunu ifade etmek doğru olmayacaktır. Zira Çin Devlet Başkanı Xi Jinping 2017 yılında 19. Çin Komünist Parti Ulusal Kongresi'nde bu mefhumu deklare etmiştir. “İnsanlık İçin Ortak Geleceğe Sahip Bir Toplum İnşasını Teşvik Etmek” başlığı altında Jinping: "Çin halkının rüyası, diğer ülke halklarının rüyalarıyla yakından bağlantılıdır; Çin Rüyası ancak barışçıl bir uluslararası ortamda ve istikrarlı bir uluslararası düzen altında gerçekleştirilebilir. Hem iç hem de uluslararası zorunluluklarımızı aklımızda tutmalı, barışçıl gelişme yolunda kalmalı ve karşılıklı fayda sağlayacak bir açılma stratejisi izlemeye devam etmeliyiz" (Jinping, 2017, 2122) demektedir. İstikrarlı bir uluslararası düzen arayışı içerisinde olduğunu zikreden ve burada kendisine merkezi bir pozisyon tayin eden Çin perspektifi için salgının gerekli şartları hazırladığı ifade edilebilir. Mezkûr perspektif CRI TÜRK haberlerinde sarih bir biçimde teşhis edilebilmektedir. Keza Zheng (2020) de China Daily gazetesindeki Covid-19 haberlerini incelediği çalışmasında iş birliği çerçevesini en çok kullanılan gayri-metaforik (inanç çerçevesi ile birlikte) çerçeve olarak bulgulamıştır.

\section{Örnek Haber 1. "İnsanlığın ortak geleceği iş birliği bekliyor”}

...Yeni koronavirüs pandemisi tüm dünya için zorlu bir test ve zorluklar ancak kolektif bir yanıtla aşılabilir. Bu nedenle insanlığın ortak geleceğini inşa etmek hiç olmak kadar önemli. Çin Halk Cumhuriyeti Xi Jinping'in de vurguladığı gibi, Beijing yönetimi küresel halk sağlığını korumak için elinden geleni yapmaya hazırdır. Herkesi tehdit eden bir düşmana karşı en büyük silah koordinasyon, dayanışma ve iş birliğidir" (CRI TÜRK, "İnsanlığın ortak geleceği iş birliği bekliyor” başlıklı haber, 09.04.2020).

\section{Örnek Haber 2. "Çin'den salgınla mücadele için dayanışma çağrısı"}

"Çin'in Birleşmiş Milletler (BM) Daimi Temsilcisi Zhang Jun, uluslararası toplumun harekete geçip, BM'nin çağrısı doğrultusunda salgınla birlikte mücadele etmesini 
SAZANER, Oben Hüseyin (2021). Haber Çerçeveleme ve Covıd-19: CRI Türk Haber Portalı İncelemesi, Gümüşhane Üniversitesi İletişim Fakültesi Elektronik Dergisi (e-gifder), 9 (2), 943-975.

beklediklerini belirtti...” (CRI TÜRK, “Çin’den salgınla mücadele için dayanışma çağrısı" başlıklı haber, 10.04.2020).

\section{Liderlik Çerçevesi}

CRI TÜRK Haber Portalı'nda Covid-19 salgının konu edinildiği haberlerde en sık kullanılan ikinci çerçeve, haber öyküsünün Çinli politikacılara ya da kabineye dayandırıldığı liderlik çerçevesidir (Luther ve Zhou, 2005: 860). Çinli liderlerin diğer devlet liderleri ile yaptıkları görüşmeler, Çinli politik figürlerin salgına ilişkin söylem ve eylemleri, Çin Komünist Partisi'nin ve hükümet organizasyonunun salgına yanıt verebilme kabiliyetine yapılan vurgu, söz konusu çerçevenin kurulduğu haberlerde işlenen belli başlı temalardır.

Çin Devlet Başkanı Xi Jinping kongre deklarasyonunda, "Tüm Eylemlerde Parti Liderliğinin Sağlanması" başlığı altında "Siyasi bütünlüğü koruma, büyük resme göre düşünme, liderlik özünü takip etme ve uyum içinde olma ihtiyacına dair bilincimizi güçlendirmeliyiz" (2017: 17) demektedir. CRI TÜRK Haber Portalı'ndaki Covid-19 haberlerinde olay öykülerinin meşruiyeti Çinli politik liderler ya da devlete ait kurumların ifadeleri üzerinden tesis edilmektedir. Haber kaynakları ekseriyetle devlet görevlileri olduğundan durum tanımları da Çin resmi devlet politikasını takip etmektedir.

\section{Örnek Haber 1. "ÇKP Merkez Komite Siyasi Bürosu toplandı"}

...Toplantıda, salgını önleme ve kontrol tedbirlerinin rutin hale getirilmesi ve diğer konulara ilişkin düzenlemeler yapıldı. ÇKP Merkez Komitesi Genel Sekreteri Xi Jinping toplantıda yaptığı konuşmada, salgınla mücadelede belli sonuçlar elde edildiğini ve ülkenin ekonomik ve sosyal düzene yeniden kavuşmakta olduğunu, ancak ithal vakaların arttığını ve ekonominin bazı yeni zorluklarla karşılaştığını belirtti (CRI TÜRK, “ÇKP Merkez Komite Siyasi Bürosu toplandı" başlıklı haber, 08.04.2020).

Örneğin yukarıdaki haberde salgının toplumsal ve ekonomik neticelerinin kontrol altında olduğu, ülkedeki tek yetkili kuruma (Çin Komünist Partisi) ve en yetkili insana (Xi Jinping) dayandırılarak aktarılmaktadır. Kimi ekonomik zorluklarla 
SAZANER, Oben Hüseyin (2021). Haber Çerçeveleme ve Covıd-19: CRI Türk Haber Portalı İncelemesi, Gümüşhane Üniversitesi İletişim Fakültesi Elektronik Dergisi (e-gifder), 9 (2), 943-975.

karşılaş1lsa da liderlik kurumunun meseleye hâkim olduğu ve gerekli düzenlemeleri yaptığı belirtilmektedir.

\section{Örnek Haber 2. "Xi'den riskleri göğüslemek için reformları derinleştirme vurgusu"}

Çin Cumhurbaşkanı Xi Jinping, riskleri göğüslemek üzere reformların derinleştirilerek, sistem avantajının yerine getirilmesi gerektiğini vurguladı. Aynı zamanda Çin Komünist Partisi (ÇKP) Merkez Komitesi Genel Sekreteri ve Merkez Askeri Komisyon Başkanı olan Xi, dün ÇKP Merkez Komitesi Reformları Kapsamlı Değiştirme Komisyonu'nun 13. Toplantısı'na başkanlık yapt. Xi, “Çin'de salgın kontrolünün ve işletmelerin yeniden iş başı yapması çalışmalarının hızlı bir şekilde ilerleyebilmesinin temel sebebi, ÇKP'nin liderliği ile Çin'in sosyalizm sisteminin avantajının söz konusu çalışmalarda oynadığı önemli rol." Diye konuştu...(CRI TURK, "Xi'den riskleri göğüslemek için reformları derinleştirme vurgusu" başlıklı haber, 28.04.2020)

\section{Tedbir ve Kontrol Çerçevesi}

Tedbir ve Kontrol çerçevesi, Çin hükümetinin Covid-19 salgınını kontrol altına alabilmek için almış olduğu önlemlerin ve salgının söz konusu önlemler neticesinde kontrol altına alınmış olduğuna ilişkin bilgilerin haberleştirildiği haber çerçevesidir. CRI TÜRK Haber Portalı'nda en sık kullanılan üçüncü haber çerçevesidir. Haber metinlerinde tedbir ve kontrol çerçevesi tespit edilirken yararlanılan anahtar kelime ve ifadeler : "Tedbir", "önlem”, "kontrol”, "karantina”, “dijital sağlık uygulamaları” gibi ifadelerdir.

Zhao'ya göre Çin, salgını sert ve sıkı tedbirlerle kontrol altına alarak bu kriz şartlarından güçlü bir konumda çıkmayı başardı ve vakit kaybetmeden Çin Halk Cumhuriyeti'nin güçlü devlet kapasitesine vurgu yaparak kendi propagandasını yapmaya koyuldu (2020: 1). CRI TÜRK Haber Portalı'ndaki tedbir ve kontrole ilişkin haber öykülerinin ekseriyeti Çin'in aldığı tedbirlere ilişkin olumlu muhteviyattaki haberlerdir. Nispeten az sayıdaki olumsuz tedbir ve kontrol haberleri ise ABD’nin önlem ve kontrol noktasındaki başarısızlıkları üzerine kuruludur. 
SAZANER, Oben Hüseyin (2021). Haber Çerçeveleme ve Covıd-19: CRI Türk Haber Portalı İncelemesi, Gümüşhane Üniversitesi İletişim Fakültesi Elektronik Dergisi (e-gifder), 9 (2), 943-975.

Tablo 3. Tedbir ve Kontrol Çerçevesi

\begin{tabular}{lll} 
& Sayı & Yüzde \\
\hline Çin-Olumlu Tedbir ve Kontrol & 85 & 60,28 \\
\hline Kavram Olarak Tedbir ve Kontrol & 32 & 22,70 \\
\hline ABD-Olumsuz Tedbir ve Kontrol & 14 & 9,93 \\
\hline Olumlu Tedbir ve Kontrol-Diğer & 9 & 6,38 \\
\hline Olumsuz Tedbir ve Kontrol-Diğer & 1 & 0,71 \\
\hline TOPLAM & 141 & 100,00 \\
\hline
\end{tabular}

\section{Örnek Haber 1. "Çin sınır geçişlerini güçlendiriyor"}

Çin Devlet Konseyi Salgını Ortaklaşa Önleme ve Kontrol Çalışmaları Mekanizması dün bir basın toplantısı düzenleyerek, yurt dışından gelen Covid-19 vakalarını önleme ve kontrol etme çalışmaları hakkındaki bilgi verdi. Toplantıda, Çin’in sınır girişlerini yasalara göre güçlendirdiği belirtildi (CRI TÜRK, “Çin sınır geçişlerini güçlendiriyor” başlıklı haber, 07.04.2020).

Örnek Haber 2. “ABD'de tedbirler erken alınsaydı daha fazla hayat kurtarılabilirdi"

...Sunucunun, "Eğer daha erken davranılsaydı, daha fazla hayat kurtarılır miydı?" sorusuna Fauci, "Mantıksal olarak öyle, bunu kimse inkar edemez. Eğer daha erken tedbirler alınsaydı daha fazla hayat kurtarılabilirdi, ancak bu tür kararların alınması karmaşıktır.” İfadelerini kullandı” (CRI TURK, “ABD'de tedbirler erken alınsaydı daha fazla hayat kurtarılabilirdi” başlıklı haber, 13.04.2020).

\section{Yardım ve Destek Çerçevesi}

Yardım ve destek çerçevesi CRI TÜRK Haber Portalı'ndaki Covid-19 salgını ile ilgili haber öykülerinde sıkça kullanılan haber çerçevelerinden biridir. Bu çerçeve uyarınca Çin hükümetinin salgınla mücadele eden pek çok ülkeye yardım ettiğinin altı çizilmekte, Çin'in salgın sürecinde küresel bir sorumluluk üstlendiği vurgulanmaktadır. Yardım ve destek çerçevesinin öne çıkarıldı̆̆ı haberlerde Çin'in farklı sosyo-ekonomik gelişmişlik düzeylerine sahip, farklı coğrafyalara ayrım yapmadan salgınla mücadele amaçlı malzemeler gönderdiği haberleştirilmiştir. 
SAZANER, Oben Hüseyin (2021). Haber Çerçeveleme ve Covıd-19: CRI Türk Haber Portalı İncelemesi, Gümüşhane Üniversitesi İletişim Fakültesi Elektronik Dergisi (e-gifder), 9 (2), 943-975.

Yardım ve destek çerçevesinin kullanıldığı 132 haberde Çin hükümetinin çok geniş coğrafyalara yardım ettiği, destek verdiği görülmektedir. Bu noktada Çin, yardım ve desteklerin küresel sorumluluk mucibince gerçekleştirildiğini ifade etmektedir; ancak sürecin politik bağlamına bakıldığında söz konusu yardım ve destekler bir yumuşak güç enstrümanı olarak okunmaya da müsaittir. Zira, gerek başını ABD’nin çektiği kimi Batılı devletler gerekse Reporters Without Borders (https://rsf.org) gibi sivil toplum kuruluşları Çin hükümetinin salgın sürecindeki performansını ciddi bir şekilde tenkit etmektedirler.

Tablo 4. Yardım ve Destek Çerçevesi

\begin{tabular}{lll} 
& Sayı & Yüzde \\
Çin Tarafından Yapılan Yardım ve Destek & 83 & 58,45 \\
\hline Karşılıklı Yardım & 18 & 12,68 \\
\hline Kavram Olarak Yardım ve Destek & 17 & 11,97 \\
\hline $\begin{array}{l}\text { Çin Sınırları İçerisinde Yapılan Yardım ve } \\
\text { Destek }\end{array}$ & 13 & 9,15 \\
\hline Çin'e Yapılan Yardım ve Destek & 11 & 7,75 \\
\hline TOPLAM & 142 & 100,00 \\
\hline
\end{tabular}

\section{Örnek Haber 1. “Çin'in AB'ye gönderdiği yardımlar Roma'ya ulaştı”}

AB Komisyonu tarafından dün yapılan açıklamada, Çin'den Covid-19 salgınıyla mücadeleye destek amacıyla gönderilen tıbbi malzemelerin İtalya'nın başkenti Roma'ya ulaştığı belirtildi (CRI TÜRK, “Çin'in AB'ye gönderdiği yardımlar Roma'ya ulaştı" başlıklı haber, 07.04.2020).

\section{Örnek Haber 2. “Afrika'da vaka sayısı artarken, Çin yardım malzemeleri gönderdi"}

...Öte yandan Çin'in 18 Afrika ülkesine sağladığı salgınla mücadele amaçlı malzemeler dün Gana'ya ulaştı. Solunum cihazı, N95 maske, koruyucu giysi ve eldivenler dahil yardım malzemeleri Gana, Senegal, Sierra Leone, Sao Tome ve Principe dahil 18 ülkeye teslim edilecek (CRI TÜRK, ““‘Afrika’da vaka sayısı artarken, Çin yardım malzemeleri gönderdi” başlıklı haber, 07.04.2020). 
SAZANER, Oben Hüseyin (2021). Haber Çerçeveleme ve Covıd-19: CRI Türk Haber Portalı İncelemesi, Gümüşhane Üniversitesi İletişim Fakültesi Elektronik Dergisi (e-gifder), 9 (2), 943-975.

\section{Sorumluluk Çerçevesi}

CRI TÜRK Haber Portalı'ndaki Covid-19 salgını ile alakalı olarak yayınlanan 350 haberden 132 haberde bulgulanan sorumluluk çerçevesi, ekseriyetle salgının ABD'deki seyrine ilişkin haber öykülerini ve Çin'e sınırları dışından gelen Covid-19 vakalarını ihtiva etmektedir. İlgili haberlerde Amerikan Hükümeti Amerika'daki salgının neticelerinden sorumlu tutulurken, Çin'deki vakalarda sınır dışından gelen vakaların yekûnuna dikkat çekilmektedir. Bunun haricinde, Salgının Çin'deki seyriyle ilgili olarak Çin hükümetinin sorumlu olduğuna ilişkin herhangi bir haber yer almazken; olumlu anlamda bilhassa Çin'in küresel sorumluluklarını yerine getirdiği belirtilmektedir. CRI TÜRK Haber Portalı'nda sorumluluk çerçevesi aranırken "sorumluluk", "günah keçisi”, “ithal vakalar" gibi ifadelerden yararlanılmıştır.

Tablo 5. Sorumluluk Çerçevesi

\begin{tabular}{lll} 
& Sayı & Yüzde \\
\hline Olumsuz Sorumluluk-ABD & 48 & 36,09 \\
\hline Olumsuz Sorumluluk-ithal Vakalar & 42 & 31,58 \\
\hline Olumlu Sorumluluk-Çin & 27 & 20,30 \\
\hline Olumsuz Sorumluluk- Diğer Batılı Ülkeler & 7 & 5,26 \\
\hline Diğer Olumsuz Sorumluk & 5 & 3,76 \\
\hline Diğer Olumlu Sorumluluk & 4 & 3,01 \\
\hline TOPLAM & 133 & 100,00
\end{tabular}

7 haberde ABD haricindeki diğer Batılı ülkelerin salgındaki sorumluluklarından olumsuz bir şekilde bahsedilirken, diğer olumsuz sorumluluk çerçevelerinde Çin'de yaşayan Afrikalılar, Rusya'dan gelen Covid-19 vakaları ve Çin'de yaşayan Müslümanlar sorumlu olarak işaretlenmektedir. Diğer olumlu sorumluk çerçevesini ise Dünya Sağlık Örgütü'ne (DSÖ) izafe edilen müspet hasletler oluşturmaktadır.

\section{Örnek Haber 1. "Adil ve eşit muamele taahhüdü"}

ÇİN'DE YAŞAYAN HERKES YASALARA UYMALI... Guangzhou'da yaşayan Afrikalılar arasında artan Covid-19 vakaları göze çarpıyor. Salgına yakalananların kontrol önlemlerine uymak istemediğine dair raporlar ve yerel 
SAZANER, Oben Hüseyin (2021). Haber Çerçeveleme ve Covıd-19: CRI Türk Haber Portalı İncelemesi, Gümüşhane Üniversitesi İletişim Fakültesi Elektronik Dergisi (e-gifder), 9 (2), 943-975.

sağlık çalışanlarına yapılan saldırılar ise vatandaşları telaşlandırdı. Bazı Amerikan medya kuruluşları ve siyasetçileri, Guangzhou yetkilileri ve Afrikalılara karşı ayrımcılık yapıldığına dair sansasyonel bilgiler yayarak Çin’e saldırma alışkanlıklarını sürdürmek istediler. Bu açıklamalar nedeniyle, Afrikalıların şehirdeki durumu hem yerel hem de uluslararası kamuoyunun dikkatini çekti (CRI TÜRK, “Adil ve eşit muamele taahhüdü” başlıklı haber, 15.04.2020).

\section{Örnek Haber 2. "Çinli sözcü: ABD hükümeti sorulara cevap vermeli”}

...Çinli sözcü Geng Shuang, son zamanlarda ABD hükümetinin salgına karş1 hızlı ve etkili tedbir alıp almamasına ilişkin soru ve endişeler çıktığına dikkat çekerek “tepki sesleri salgının ABD’de ne zaman başladığı, hükümeti neleri sakladığı, salgın sorumluluğunu neden başka ülke ve uluslararası kuruluşların sırtına yüklediği gibi alanları kapsıyor. ABD hükümetinin, kendi halkının ve uluslararası toplumun endişelerini zamanında gidermesini bekliyoruz" şeklinde konuştu (CRI TÜRK, “Çinli sözcü: ABD hükümeti sorulara cevap vermeli” başlıklı haber, 27.04.2020).

\section{Çatışma Çerçevesi}

Çatışma çerçevesi CRI TÜRK haber portalında Covid-19 haberlerinde en sık kullanılan çerçevelerden biridir. Diğer baskın çerçevelerle olan yakın ilişkisi bu çerçeveye hususi bir ihtimamı lüzumlu kılmaktadır (Örneğin çatışma çerçevesinin olduğu pek çok haberde iş birliği çerçevesi de mevcuttur). İlgili çerçeve bilhassa Amerika Birleşik Devletleri'nin, Amerikan Başkanı Donald Trump'ın, Amerika Birleşik Devletleri Dışişleri Bakanı Mike Pompeo'nun ve başını Amerikan medyasının çektiği Batı medyasının konu edildiği haberlerde görülmektedir. Çatışma çerçevesinin kurulduğu haberlerde Çin hükümetinin muarızları olarak Batılı devletler (ABD, İngiltere, Avustralya), Batılı yayın organları, Batılı politik figürler birer aktör olarak yer almaktadır. Söz konusu haberlerde zikredilen aktörler ile Çin arasındaki çatışma, kimi zaman dolayımsız olarak aktarılırken, kimi zaman DSÖ ya da Çin'de 
SAZANER, Oben Hüseyin (2021). Haber Çerçeveleme ve Covıd-19: CRI Türk Haber Portalı İncelemesi, Gümüşhane Üniversitesi İletişim Fakültesi Elektronik Dergisi (e-gifder), 9 (2), 943-975.

yaşayan Afrikalılar'ın -Covid-19 salgını bağlamında- içinde bulundukları koşullar ${ }^{1}$ üzerinden okuyucuya ulaştırılmaktadır.

CRI TÜRK haber metinlerinde çatışma çerçevesinin izi sürülürken; "ticaret savaşı, "Çin karşıtlığı”, "tazminat”, "saldırı”, "suçlama”, “yalan”, “Covid 19 salgınını siyasallaştırma", "sistemsel karşılaştırma", "Çin'in insan haklarını ihlal ettiği iddiası" gibi anahtar sözcük ve ifadelerden istifade edilmiştir.

Çin ile ABD arasındaki aleni çatışma yalnızca Covid-19 sürecine münhasır olmayıp, evveliyatı iki ülkenin aralarındaki ticaret savaşında temellenmektedir. İki ülke 2018 y1lında birbirlerinden gerçekleştirdikleri ithalata ek vergiler koymuşlardır ${ }^{2}$. Ancak bu iki ülkenin misilleme olarak aldığ 1 kararlarda Çin aleyhine bir dengesizlik söz konusudur. Bu vaziyetin sebebi ise 2017'de Çin'in ABD'ye ürün ihracatı 505 milyar dolarken, ABD’nin Çin'e ihracatının ise sadece 130 milyar dolar olmasıdır (Liu ve Woo, 2018: 2). Söz konusu vakıa CRI TURK'ün ABD ile olan çatışma haberlerinde neden çoğunlukla işbirliği temennilerine de yer verdiğini açıklamaktadır.

Kısaca, üç endişe ABD’nin Çin'e yönelik bir ticaret mücadelesi başlatmasına neden olmuştur: İlki, Çin'in git gide büyüyen ticaret fazlasının ABD'de istihdam yaratılmasına engel teşkil ettiği düşüncesi; ikincisi, Çin'in ABD teknolojisini adilane olmayan yöntemlerle iktibas ettiği kaygısı (Çin pazarına girmek isteyen bir firmanın hükümet bağlantılı yerel bir firma ile ortaklık kurmaya zorlanması ve bunun neticesinde ilgili firmanın teknoloji bilgisinin Çin firmalarına geçmesi); sonuncu olarak da Çin'in ABD'nin ulusal güvenliğini ve uluslararası pozisyonun zayıflatmaya çalıştı̆̆ı endişesi (Liu ve Woo, 2018: 2-16).

\footnotetext{
${ }^{1} 2020$ Nisan ayının ortalarında Çin'in Guangzhou şehrinde Covid-19 pandemisinin müsebbibi olarak Afrikalıların görüldüğü ve ayrımcılığa uğradıklarına yönelik iddialar haberleştirilmiştir. (https://www.ntv.com.tr, 2020).

${ }^{2}$ ABD 2018 yılında, Çin'den ithal edilen 50 milyar dolarlık Çin ürününe yüzde yirmi beşlik bir gümrük vergisi uyguladı. Çin de buna misilleme olarak 128 ABD ürününe yüzde yirmi beşlik ek gümrük vergisi getirdi. Çin'in hamlesine tepki olarak ABD, 200 milyon dolarlık Çin malına yüzde yirmi beş gümrük vergisi uygulayacağını deklare etti. Çin, bu girişime 60 milyar dolarlık $A B D$ ürününe yüzde yirmi beş vergi ile mukabele etti (Liu ve Woo, 2018: 2; Herrero, 2019:2; https://www.bbc.com, 2020).
} 
Tablo 6. Çatışma Çerçevesi

\begin{tabular}{lll} 
& Sayı & Yüzde \\
\hline ABD ile Çatışma & 84 & 75,68 \\
\hline Diğer Batı Ülkeleri ile Çatışma & 11 & 9,91 \\
\hline Batı Basını ile Çatışma & 10 & 9,01 \\
\hline İngiltere ile Çatışma & 6 & 5,41 \\
\hline TOPLAM & 111 & 100,00 \\
\hline
\end{tabular}

\section{Örnek Haber 1. "Çin Karşıtlı̆̆ı Salgına Çözüm Değil”"}

Amerika Birleşik Devletleri (ABD) ve diğer Batı ülkeleri son zamanlarda Çin'e karşı sürekli değişen perspektiflerinden saldırılar başlattı. Çin’i Covid19 vaka sayısını ve ölümler hakkındaki verileri gizlemekle suçladılar. Çin'den Batı'ya gönderilen bazı tıbbi malzemelerin kalitesi ile ilgili anlaşmazlıklar üzerinden Çin'in diplomasisine çamur attılar. Çin'in koronavirüs salgından sorumlu tutulmasını talep ettiler. Çin karşıtı yeni bir koro kurarak çığlık atmayı sürdürüyorlar.

$\mathrm{Bu}$ koronun ortaya çıkmasının üç nedeni vardır. İlk olarak, Çin’e karşı paranoyak duruşa sahip bazı kuvvetler, mevcut koşullar altında kaçınılmaz olarak bu şekilde tepki vermek istedi. İkincisi, Çin salgını kontrol altına alırken, $A B D$ ve Avrupa ülkeleri ciddi şekilde salgından etkileniyor. Üçüncüsü, Batı'daki iktidarlar ve ideolojik seçkinler, halka içinde bulundukları zor durumu açıklayamadılar, bu nedenle Çin'i günah keçisi haline getirerek öfke saçmayı tercih ettiler (CRI TÜRK, "Çin Karşıtlığı Salgına Çözüm Değil” başlıklı haber, 01.04.2020).

Van Dijk'a göre bir metindeki ideolojik damarın varlığını ikrar eden olgu biz ve onlar dikotomisi ve bu dikotomi etrafında örgütlenmiş söylemdir. Buradan hareketle Van Dijk ideolojik bir söylemin dört genel stratejik ilkesi olduğunu ifade eder: Bizim hakkımızda olumlu şeyleri vurgula, onlar hakkında olumsuz şeyleri vurgula, bizim hakkımızda olumsuz şeyleri vurgulama, onlar hakkında olumlu şeyleri vurgulama (2015: 52-53). Söz konusu projeksiyondan haber metnine bakıldığında biz ve onlar kategorilerinin aktörleri Çin Halk Cumhuriyeti ve Amerika Birleşik Devletleri'dir. Metinde ABD ve isimleri zikredilmeyen diğer Batılı ülkeler 
SAZANER, Oben Hüseyin (2021). Haber Çerçeveleme ve Covıd-19: CRI Türk Haber Portalı İncelemesi, Gümüşhane Üniversitesi İletişim Fakültesi Elektronik Dergisi (e-gifder), 9 (2), 943-975.

Çin'in agresif ötekileri olarak işaretlenmiştir. Yine, metinde işlendiği şekliyle Batılı bloğun Çin karşıtlığının mesnetsiz olduğu ve bunun ciddi bir psikolojik veçhesinin bulunduğu belirtilmektedir. Akabinde Çin ile $A B D$ ve Avrupa ülkelerinin salgınla mücadele performansları kontrasta sokularak Çin lehine müspet ve ehliyetli bir imaj inşa edilmiştir.

\section{Örnek Haber 2. "Çin'e Saldırmak Virüsü Bitirmeyecek”}

SALGINA ODAKLANMA ZAMANI...Bu arada, Batı medya kuruluşları da boş durmayarak Çin'e karşı suçlamalar yöneltmeye devam etti. Covid-19 salgını, bazı Batı hükümetlerinin acil durumla başa çıkmadaki zayıflığını ve boşluğunu ortaya çıkardı. Batı' daki bazı politikacılar beceriksizliklerini Çin'i suçlayarak örtmeye çalışıyor. Bu politikacılar sadece kişisel siyasi çıkarlarını önemsiyorlar ve koronavirüse karşı verilen savaştan firsat çıkarmayı planlıyorlar... Bazı Batılı politikacıların Çin'i salgından dolayı dünyaya tazminat ödemeye çağırması kocaman bir rüya. Bunun yasal bir temeli yoktur. Sözde tazminat mekanizmaları göz önüne alındı̆̆ında, ABD dünyaya getirdiği AIDS ve H1N1 salgını için ne kadar para ödemesi gerekecek? (CRI TÜRK, “Çin’e Saldırmak Virüsü Bitirmeyecek” başlıklı haber, 02.04.2020).

Haber metninde yine öteki olarak Batılı medya kuruluşları, kimi Batılı hükümetler işaret edilmektedir. Mevzu bahis hükümetlerin salgınla mücadeledeki başarısızlıklarına dikkat çekilerek Çin’in müspet farkının altı çizilmektedir. Tajfel ve Turner'a göre pozitif sosyal kimlikler iç grup ve diş grup arasında iç grup lehine yapılan mukayeselere dayanmaktadır (1986: 16). Pozitif sosyal kimlik iç grup mensuplarına prestijli bir sosyal kimlik temin eder ve iç grup aidiyetini sağlar (Tajfel ve Turner: 1986). Global Times'ın yaptığı bu haberin hedef kitlesi iç grup değildir; ancak uluslararası toplumda itibarlı bir temsil hedefi aşikârdır. Çin’e yönelik olası tazminat taleplerine ilişskin iddialara ise AIDS ve H1N1 virüsleri ile mukabele edilerek, söz konusu hastalıkların müsebbibi olarak ABD işaret edilmiştir.

\section{Ekonomik Sonuçlar Çerçevesi}

CRI TÜRK Haber Portalı'ndaki Covid-19 salgınının ekonomik sonuçları ile çerçevelenen haberlerde inşa edilen olumlu bağlam dikkat çekmektedir. Nitekim 
SAZANER, Oben Hüseyin (2021). Haber Çerçeveleme ve Covıd-19: CRI Türk Haber Portalı İncelemesi, Gümüşhane Üniversitesi İletişim Fakültesi Elektronik Dergisi (e-gifder), 9 (2), 943-975.

2020 yılı Nisan ayı içerisinde ekonomik sonuçlar çerçevesiyle yayınlanan haberlerin çoğunluğu olumlu bir bağlam içerisinde aktarılmıştır. Haber metinlerinde Çin hükümetine ve onun ekonomi politikalarına duyulan güvene vurgu yapılırken, salgının yarattığ menfi ekonomik atmosferin kendi içerisinde fırsatlar içerdiğine de değinilmektedir. Olumsuz olarak çerçevelenen ekonomik haberler ise daha çok küresel düzeydeki kötü ekonomik gelişmeler ve ABD'nin salgından ekonomik anlamda olumsuz etkilendiğine dair bilgilerdir.

Tablo 7. Ekonomik Sonuçlar Çerçevesi

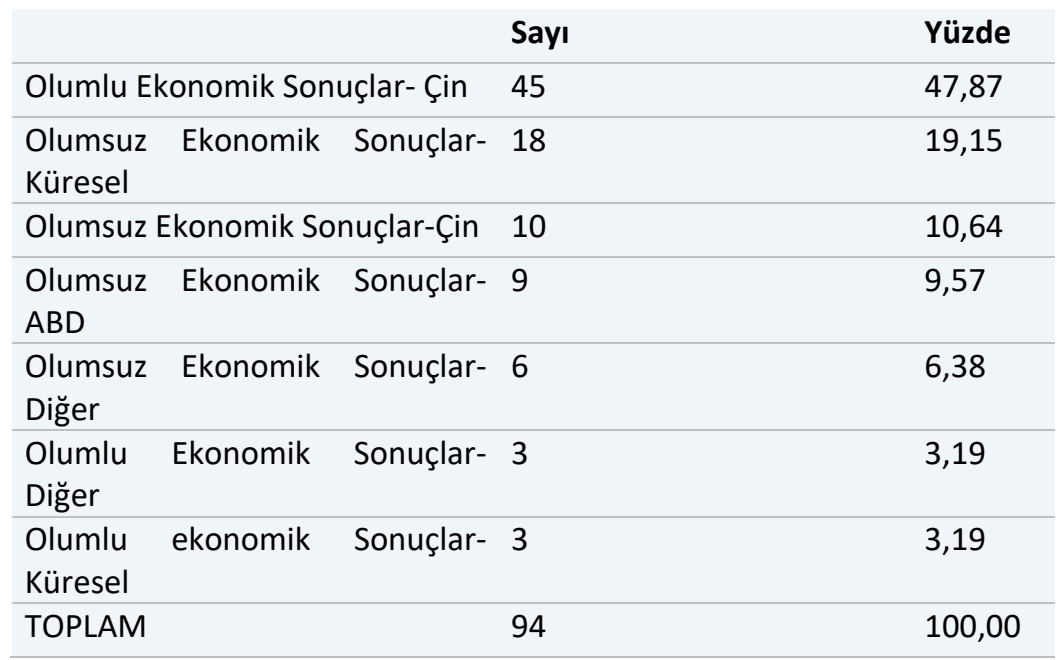

\section{Örnek Haber 1. "Canlandırma planı iyileşmeye yol açacak"}

ÇİN EKONOMISII TOPARLANIYOR...Yeni koronavirüs salgını, küresel ekonomik büyümede belirgin bir düşüşe neden oldu. Çin ekonomisi, 2020 yılının ilk çeyreğinde yıllık yüzde 13,2 düşüşle yüzde 6,8 daraldı. Ancak Çin ekonomisinin ikinci çeyrekte hızlı bir şekilde toparlanması ve olumsuzdan olumlu büyümeye dönmesi bekleniyor. Salgının neden olduğu ters V-şekilli büyüme eğrisini $\mathrm{V}$-şekilli bir büyüme eğrisine dönüştürmek için ülkenin ekonomik canlandırma planı başlatması gerekiyor (CRI TÜRK, “Canlandırma planı iyileşmeye yol açacak”, başlıklı haber, 29.04.2020)

\section{Sayılarla Belirtme Çerçevesi}

Dünyadaki tüm haber ajansları ve merkezleri gibi CRI TÜRK Haber Portalı da salgının şiddetini ölçülebilir kılmak için sayısal verilerden yararlanmaktadır. 
SAZANER, Oben Hüseyin (2021). Haber Çerçeveleme ve Covıd-19: CRI Türk Haber Portalı İncelemesi, Gümüşhane Üniversitesi İletişim Fakültesi Elektronik Dergisi (e-gifder), 9 (2), 943-975.

Haber metinlerinde açıklanan vaka sayılarının büyük bir bölümünün ithal vakalar yani yurtdışından gelen vakalar olduğunun belirtilmesi dikkat çekicidir.

\section{Örnek Haber 1. " Çin'de 32 yeni ithal Covid-19 vakası"}

Çin'in ana kesiminde dün gece itibariyle 32 Covid-19 vakası tespit edildiği, bu vakalardan hepsinin yurt dişından geldiği bildirildi (CRI TÜRK, “Çin’de 32 yeni ithal Covid-19 vakası" başlıklı haber, 07.04.2020).

\section{Bilimsel ve Tıbbi Gelişme Çerçevesi}

Bilimsel ve Tıbbi Gelişme çerçevesi ( $\mathrm{Bu}$ çalışmanın özgül koşulları çerçevesinde literatürden iktibas edilen bilimsel gelişme çerçevesi (Çeliker Saraç, 2018) bilimsel ve tıbbi gelişme çerçevesi şeklinde revize edilmiştir) CRI TÜRK Haber Portalı'nda Covid-19 salgını ile alakalı haberlerde nispeten az tercih edilen bir haber çerçevesidir. Bilimsel-tıbbi gelişmelerin, girişimlerin konu edinildiği haber çerçevesinin CRI TÜRK sayfalarındaki Covid-19 haberlerinde 49 adet haberde mevcut olduğu tespit edilmiştir.

\section{Örnek Haber 1. "Dünya'da ilk: Çin'de Covid-19 aşısının ikinci aşama klinik} testleri başladı"

Çin askeri Bilimler Akademisi tarafından geliştirilen Covid-19 aşısının ikinci aşama klinik denemeleri önceki gün başladı. Dünya Sağlık Örgütü'nün (DSÖ) sitesinde yer alan açıklamada, söz konusu alt birim aşının şu an dünyada ikinci aşama klinik denemeleri başlayan ilk Covid-19 aşısı olduğuna işaret edildi (CRI TÜRK, “Dünya'da ilk: Çin'de Covid-19 aşısının ikinci aşama klinik testleri başladı” başlıklı haber, 14.04.2020).

\section{Tanık Gösterme Çerçevesi}

Tanık Gösterme çerçevesi CRI TURK Haber Portalı'ndaki Covid-19 salgınına ilişkin haberlerde nispeten az kullanılan bir haber çerçevesidir. İlgili çerçevenin öne çıktığı haberlerde Çin'in salgınla mücadele yöntemleri ya da salgına ilişkin Çin'e yönelik ithamlar dünyanın muhtelif ülkelerinden kanaat önderlerinin şahitliğinde doğrulanmakta ya da yanlışlanmaktadır. Söz konusu kanaat önderleri uluslararası kuruluş temsilcileri, muhtelif ülkelerden politikacılar, bürokratlar, 
SAZANER, Oben Hüseyin (2021). Haber Çerçeveleme ve Covıd-19: CRI Türk Haber Portalı İncelemesi, Gümüşhane Üniversitesi İletişim Fakültesi Elektronik Dergisi (e-gifder), 9 (2), 943-975.

gazeteciler, iş insanları, akademisyenler gibi geniş yelpazeden insanları ihtiva etmektedir.

Örnek Haber 1. "Trump ve Trump gibilerin suçlamasının hiçbir anlamı yok"

...Usta belgeselci, haber fotoğrafçısı ve gazeteci Coşkun Aral, dün sosyal medya hesabından bir video paylaşt1... “BU SALGIN ÇİN'DEKİ YARASADAN KAYNAKLANIYOR” DEMEK KADAR ABES VE YANLIŞ BİR ŞEY OLAMAZ. Virüsler ile ilgili çok sık bahsedilen mutasyon konusundan söz eden Aral, "Mutasyona uğrayabiliyor. Bizde nasıl bazı şeyler 'kanserojen' denip yemememiz tercih ediliyorsa bazı hayvanları da yediklerinde onların ortaya koydukları kendilerinde zararlı olmayan ama başkasına geçtiğinde zarar verecek virüs ve bakterilerin oluşumu gayet doğaldır...(CRI TURK, "Trump ve Trump gibilerin suçlamasının hiçbir anlamı yok" başlıklı haber, 06.04.2020).

\section{İnsan İlgisi Çerçevesi}

İnsan ilgisi çerçevesi CRI TÜRK Haber Portalı'ndaki Covid-19 salgınına ilişkin yayınlanan haberlerde nispeten az tercih edilen bir haber çerçevesidir. Covid19 salgınına ilişkin 350 haberden 17 adedinde insan ilgisi çerçevesi tespit edilmiştir. CRI TÜRK Haber Portalı'nda insan ilgisi çerçevesi içerisinde kurulan haber öykülerinde salgın sıradan insanların gözünden aktarılmış ya da salgın sürecinde etkilenen veya hayatını kaybeden insanlar duygusal veçhesi yüksek haber anlatıları vasıtasıyla okuyucunun bilgisine sunulmuştur. İnsan ilgisi çerçevesi söz konusu haberlerin hepsinde olumlu bir bağlam içerisinde yapılandırılmıştır.

\section{Örnek Haber 1. “Çin'de salgınla mücadeleye katılan sağlık personelinin hikayeleri kitaplaştırıldı"}

Çin'de Covid-19 salgınıyla mücadeleye katılan doktor ve hemşirelerin deneyimlerini anlattıkları "Meleklerin Günlükleri” adlı kitap 25. Dünya Okuma günü vesilesiyle bugün raflardaki yerini aldı (CRI TÜRK, “Çin'de salgınla mücadeleye katılan sağlık personelinin hikayeleri kitaplaştırıldı” başlıklı haber, 23.04.2020). 
SAZANER, Oben Hüseyin (2021). Haber Çerçeveleme ve Covıd-19: CRI Türk Haber Portalı İncelemesi, Gümüşhane Üniversitesi İletişim Fakültesi Elektronik Dergisi (e-gifder), 9 (2), 943-975.

\section{Ahlak Çerçevesi}

Herhangi bir meseleyi ya da o meselenin tesirlerini ahlaki değer yargıları perspektifinden değerlendirmeye dayanan ahlak çerçevesi (Neuman vd'lerinden Akt., Semetko ve Valkenburg, 2000) CRI TÜRK Haber Portalı'nda yalnızca bir defa kullanılmıştır.

\section{Örnek Haber 1. “COVİD-19 terimleri ticari marka olarak kullanılabilir mi?”}

KANUNLAR İZIN VERMIYOR... Çin Ulusal Fikri Mülkiyet Ofisi istatistikleri, salgının başlangıcından bu yana COVID-19 ile ilgili, 1,500'den fazla marka tescil başvurusunun yapıldığını açıkladı. Bazı ticari işletmeler tüketicileri cezbetmek için popüler kelimeleri marka haline getirmek isteyebilir. Örneğin bazı ünlü mekanların veya kişilerin ismi marka haline getirilmiştir. Ancak COVID-19 salgını için bu düşünülemez. Çünkü salgınla ilgili kelimelere ticari markaların tescili getirilmesi yasal olmaktan ahlaki yönden etik değildir. Bu uygulama, geçen kasım ayında yürürlüğe giren yeni revize edilmiş Çin Ticari Marka Yasasına da aykırıdır (CRI TÜRK, “COVID-19 terimleri ticari marka olarak kullanılabilir mi?” başlıklı haber, 25.04.2020).

\section{SONUÇ}

Covid-19 salgınının tüm dünyada yıkıcı etkiler yarattığı bir zaman diliminde, bir yandan ülkeler salgının yarattığı ya da yaratacağı toplumsal ve ekonomik krizleri gögüslemeye çalışırken; öte yandan uluslararası toplumda salgına yönelik ihmallerin faillerine yönelik tartışmalar da varlığını sürdürmektedir. Başını ABD’nin çektiği bazı Batılı ülkeler ve medya organları virüsün yayılımından Çin'i sorumlu tutmuşlardır. $\mathrm{Bu}$ çalışmada salgın sürecinde meydana gelen hadiselerin Çin devletinin söylemlerini yansıtan CRI TÜRK Haber Portalı'nda hangi biçimlerde çerçevelendiğinin yanıtı aranmıştır. Söylem alanındaki güç mücadelesi Çin devletinin öz iktidarının yeniden üretilmesiyle ilişkili anlam kümeleri üzerinden okunmaya çalışı1mıştır.

Jakop'a göre, Covid 19 salgını ile birlikte Çin'in uluslararası topluma yönelik olarak gerçekleştirdiği iletişim yönetimi, parti liderliğinin ülkenin yurt dişındaki imajına ne denli önem verdiğini göstermektedir. Yine Jakop, Çin'in yurt dişına 
SAZANER, Oben Hüseyin (2021). Haber Çerçeveleme ve Covıd-19: CRI Türk Haber Portalı İncelemesi, Gümüşhane Üniversitesi İletişim Fakültesi Elektronik Dergisi (e-gifder), 9 (2), 943-975.

yönelik olarak anlattığı öyküleri yerel vaziyetle ilişkilendirmekte ve bu suretle parti liderliğinin, yurttaşların haklarından devlet lehine feragat ettiği mevcut toplumsal düzeni tahkim ettiğini öne sürmektedir (2020: 12). Dolayısıyla, Türkiye Çin Halk Cumhuriyeti için oldukça önemli bir ülke görünümündedir. Zira Türkiye'de 1950'li yıllardan beri azımsanmayacak bir Uygur nüfus ve Uygur meselesinin insan hak ve hürriyetleri çerçevesinde çözümlenmesini talep eden bir kamuoyu bulunmaktadır. $\mathrm{Bu}$ doğrultuda Türkiye'ye yönelik iletişim faaliyeti Çin için elzem mahiyettedir.

Çin hükümetinin bakış açısını temsil eden CRI TÜRK Haber Portalı'nda en sık kullanılan çerçeveler sırasıyla iş birliği, liderlik, tedbir ve kontrol, yardım ve destek, sorumluluk ve çatışma çerçeveleridir. Çin'in küresel sorumluluk aldığını ima eden iş birliği çerçevesinde uluslararası toplumun salgına karşı dayanışma içerisinde olması gerektiğinin altı çizilmektedir. Çin, mevzubahis usulle virüsün yayılmasına ilişkin sorumluluğu olduğu iddialarına mukabele etmeye çalışmaktadır. Salgın ile ilişkili 350 haberin 348'inin haber kaynaklarının Çin devletine ait haber merkezleri olması hasebiyle liderlik çerçevesi de en sık kullanılan çerçeveler arasındadır. Hadiselere yönelik yaklaşımlar Çinli politik figürlere dayandırılarak meşrulaştırılmaktadır. Tedbir ve kontrol çerçevesi içerisine dâhil edilen haberlerin ekseriyetini Çin'in almış olduğu olumlu tedbir ve kontroller oluşturmaktadır. Olumsuz tedbir ve kontrole ilişkin haberlerde ise ABD'nin tedbir ve kontrol noktasındaki yetersizlikleri işlenmektedir. Yine, küresel sorumluluk üstlenildiğini ima eden yardım ve destek çerçevesi en çok kullanılan çerçevelerden birini oluşturmaktadır. Bu çerçevenin kullanıldığı haberlerde Çin'in salgınla mücadele noktasında pek çok ülkeye yardım ettiği belirtilmektedir. CRI TURK Haber Portalı'nda sık kullanılan bir diğer haber çerçevesi sorumluluk çerçevesidir. Söz konusu çerçeveyi ihtiva eden haberlerde ABD'nin salgındaki sorumlulukları hatırlatılmakta, Çin'e yurt dışından gelen ithal Covid-19 vakalarının altı çizilmektedir. Çin hükümetinin olumsuz anlamda sorumlu tutulduğu herhangi bir habere rastlanılmamıştır. 2020 Nisan ayı boyunca uluslararası düzlemde cereyan eden sorumluluk münakaşaları CRI TÜRK haberlerinde güçlü akisler bulmuş ve salgın haberlerinde en çok kullanılan çerçevelerden biri de çatışma çerçevesi olmuştur. İlgili haber metinlerde bilhassa ABD ile yaşanan ihtilaflara geniş yer 
SAZANER, Oben Hüseyin (2021). Haber Çerçeveleme ve Covıd-19: CRI Türk Haber Portalı İncelemesi, Gümüşhane Üniversitesi İletişim Fakültesi Elektronik Dergisi (e-gifder), 9 (2), 943-975.

verilmiştir. CRITURK Haber Portalı'nda en az kullanılan haber çerçeveleri ise sırasıyla ekonomik sonuçlar, sayılarla belirtme, bilimsel ve tıbbi gelişme, tanık gösterme, insan ilgisi ve ahlak çerçeveleridir.

\section{KAYNAKÇA}

AYDEMİR, Emrah (2019). "Çin'in Küresel Bir Yumuşak Güç Hareketi: CGTN'nin İncelenmesi", AVRASYA Uluslararası Araştırmalar Dergisi, 7 (19), s. 260 275.

BBC, https://www.bbc.com/turkce/haberler-dunya-43614766/, Erişim Tarihi: 09.05.2020.

BEAUDOİN, Christopher E. (2007). "Sars News Coverage And Its Determinants In China And The Us. The International Communication Gazette, 69 (6), p. $509-524$.

ÇELIKKER SARAÇ, Duygu (2018). "Domuz Gribi Haberlerinde Çerçeveleme: Hürriyet Gazetesi Örneği", Global Media Journal , 8 (16), s. 161-185.

DURSUN, Çiler (2004). Haberde Gerçekliğin İnşa Edilmesi Ne Demektir?, (Editör), Çiler Dursun, Haber Hakikat İktidar İlişkisi, Ankara: Elips, s. 37-66.

ENTMAN, Robert M. (1991). "Framing U.S. Coverage of International News: Contrasts in Narratives of the KAL and Iran Air Incidents", Journal of Communication, 41 (4), p. 6-27.

ENTMAN, Robert M. (1993). "Framing: Toward Clarification of a Fractured Paradigm", Journal of Communication, 43 (4), p. 51-58.

EUvsDISINFO.EU, $\quad$ https://euvsdisinfo.eu/eeas-special-report-update-shortassessment-of- narratives-and-disinformation-around-the-covid-19pandemic/, Erişim Tarihi: 02.05.2020.

FREEDOM HOUSE; (2020), "Freedom in the World /China", https://freedomhouse.org/country/china/freedom-world/2020/, Erişim Tarihi: 12.05.2020 
SAZANER, Oben Hüseyin (2021). Haber Çerçeveleme ve Covıd-19: CRI Türk Haber Portalı İncelemesi, Gümüşhane Üniversitesi İletişim Fakültesi Elektronik Dergisi (e-gifder), 9 (2), 943-975.

GITLIN , Todd (1980). The Whole World Is Watching? mass media in the making \& unmaking of the new left. Berkeley: University of California Press.

HALL, Stuart (1994). İdeolojinin Yeniden Keşfi: Medya Çalışmalarında Baskı Altında Tutulanın Geri Dönüşü, (Editör), Mehmet Küçük, Medya, İktidar, İdeoloji, Ankara: Ark, s. 57-103.

HERRERO, Alicia Garcia (2020). "Europe in the Midst of China-US Strategic Economic Competition: What are the European Union's Options?" Journal of Chinese Economic and Business Studies, 17 (4), p. 1-21.

HERTOG, James K. ve MCLEOD Douglas M. (2001). A Multiperspectival Approach to Framing Analysis: A Field Guide, (Editörler), Stephen D. Reese, Oscar H. Gandy, Jr, August E. Grant. Framing Public Life Perspectives on Media and Our Understanding of the Social World, Mahwah, New Jersey: Lawrence Erlbaum Associates, Publishers, p. 141-162

HONG, Trac1 (2007). "Information Control in Time of Crisis: The Framing of SARS in China-based Newspapers and Internet Sources", CYBERPSYCHOLOGY \& BEHAVIOR, 10 (5), p. 696-699.

İNAL, Ayşe (1995). "Yazılı Basın Haberlerinde "Yapısal" Yanlılık Sorunu", Toplum ve Bilim, 67, s.111-133.

JAKOB, Jabin T. (2020). "'"To Tell China's Story Well': China's International Messaging during the COVID-19 Pandemic", China Report, 56 (3), p. 1-19.

JiNPING, Xi (2017). "Secure a Decisive Victory in Building a Moderately Prosperous Society in All Respects and Strive for the Great Success of Socialism with Chinese Characteristics for a New Era", 19. National Congress of the Communist Party of China, 17 Ekim 2017, Beijng.

LEE, Chin- Chuan (2010). Bound to Rise: Chinese Media Discourses on the New Global Order, (Editörler), Michael Curtin ve Hemant Shah, Reorienting Global Communication Indian and Chinese Media Beyond Borders, Chicago: University of Illinois Press, p. 260-283. 
SAZANER, Oben Hüseyin (2021). Haber Çerçeveleme ve Covıd-19: CRI Türk Haber Portalı İncelemesi, Gümüşhane Üniversitesi İletişim Fakültesi Elektronik Dergisi (e-gifder), 9 (2), 943-975.

LIU, TAO ve WOO Wing Thye (2018). "Understanding the U.S.-China Trade War", China Economic Journal, 11 (3), p. 1-22.

LUTHER, Catherine A. ve ZHOU Xiang (2005). "Withın The Boundaries Of Politics: News Framing Of Sars In China And The United States", J\&MC Quarterly, 82 (4), p. 857-872.

MİLLIYET GAZETESİ, https://www.milliyet.com.tr/yerel-haberler/istanbul/kureselbir-medya-markasi-daha-turkiyeye-merhaba-dedi-11633322/, Erişim Tarihi: 05.05.2020.

NTV.COM.TR, https://www.ntv.com.tr/dunya/trump-corona-virus-salgini-nedeniylecini-sucladi,H9ynFZQeXkuQgk5HceJ6nA, Erişim Tarihi: 02.05.2020.

NTV.COM.TR, https://www.ntv.com.tr/dunya/cinde-afrikalilara-ayrimcilik-iddiasicorona-viruste-ikinci-dalga,bwJZ4lpVj0q1NmwtFNugCA/, Erişim Tarihi: 08.05.2020.

POLITICO.EU, $\quad$ https://www.politico.eu/article/russia-china-disinformationcoronavirus-covid19-facebook-google/, Erişim Tarihi: 02.05.2020.

REPORTERS WITHOUT BORDERS; (2020). "Index in the Time of Coronavirus/Countries", https://rsf.org/en/countries/, Erişim Tarihi: 12.05.2020.

SEMETKO, Holli A. ve VALKENBURG Patti M. (2000). "Framing European Politics: A Content Analysis of Press and Television News", Journal of Communication, 50 (2), p. 93-109.

SUN, Wanning. (2010). "Mission Impossible? Soft Power, Communication Capacity, and the Globalization of Chinese Media", International Journal of Communication, 4, p. 54-72.

SUN, Wanning (2014). "Foreign or Chinese? Reconfiguring the Symbolic Space of Chinese Media", International Journal of Communication, 8, p. 1894-1911.

TAJFEL, Henri ve TURNER, John C. (1986). The Social Identity Theory of Intergroup Behavior, (Editörler), William G. Austin ve Stephen Worchel, Psychology of Intergroup Relations, Chicago: Hall Publishers, p. 7-24. 
SAZANER, Oben Hüseyin (2021). Haber Çerçeveleme ve Covıd-19: CRI Türk Haber Portalı İncelemesi, Gümüşhane Üniversitesi İletişim Fakültesi Elektronik Dergisi (e-gifder), 9 (2), 943-975.

VAN DIJK, Teun (2015). Söylem ve İdeoloji: Çok Alanlı Bir Yaklaşım, (Editörler), Barış Çoban ve Zeynep Özarslan, Söylem ve İdeoloji, İstanbul: Su, s. 15100.

VREESE, Claes H. De (2005). " News framing: Theory and typology", Information Design Journal, 13 (1), p. 51-62.

YANG, Aimei (2012). "Understanding the Changing Chinese Media: Through the Lens of Crises", China Media Research, 8 (2), p. 63-75.

ZHAO, Suisheng (2020). "Rhetoric and Reality of China's Global Leadership in the Context of Covid-19: Implications for the US-led World Order and Liberal Globalization", Journal of Contemporary China, 30 (128), p. 1-16.

ZHENG, Shuyuan (2020). "The Communication Power of Chinese Novel Coronavirus Pneumonia (COVID-19) News Reports in Lights of the Framing Theory", Theory and Practice in Language Studies, 10 (11), p. 1467-1470. 
SAZANER, Oben Hüseyin (2021). Haber Çerçeveleme ve Covıd-19: CRI Türk Haber Portalı İncelemesi, Gümüşhane Üniversitesi İletişim Fakültesi Elektronik Dergisi (e-gifder), 9 (2), 943-975

Çalışma tek bir yazar tarafından yürütülmüştür.

Çalışma kapsamında herhangi bir kurum veya kişi ile çıkar çatışması bulunmamaktadır.

Araştırmanın taslak bir metinden bilimsel bir çalışmaya dönüşmesi sürecinde görüş ve önerilerinden istifade ettiğim kıymetli hocam Prof. Dr. Melike Aktaş'a teşekkür ederim. 